DOI: 10.36910/6775-2524-0560-2020-39-07

УДК: 621.313 .33

Kostiuchko Serhii Mykolaiovych, Ph.D.

https://orcid.org/0000-0002-1262-6268

Kyryliuk Liudmyla Mykolaivna, master

Kalys Oleh Viacheslavovych, student

Sibanda Zeti Fortune, student

Havryliuk Stanislav Andriiovych, student

Lutsk National Technical University

\title{
THE MONODROMY MATRIX CONSTRUCTION FOR EXECUTIVE OBJECT OF A NONLINEAR SYSTEM.
}

Костючко С.М., Кирилюк Л.М., Кались О.В., Сібанда З.Ф., Гаврилюк С.А. Побудова матриці монодромії виконавчого об'скта нелінійної системи. У статті розкрито один із методів побудови матриці монодромії, розкрито суть найпростішої побудови та обчислення такої матриці. За цим методом будується математична модель виконавчого пристрою, яка може бути використана для дослідження перехідних та усталених станів.

Ключові слова: матриця монодромії, математична модель, асинхронний мотор, рівняння стану.

Костючко С.Н., Кирилюк Л.Н., Калысь А.В., Сибанда З.Ф., Гаврилюк С.А. Построение матрицы монодромии исполнительного объекта нелинейной системі. В статье раскрыт один из методов построения матрицы монодромии, раскрыта суть самой простой построения и вычисления такой матрицы. По этому методу строится математическая модель исполнительного устройства, которая может быть использована для исследования переходных и установившихся состояний.

Ключевые слова: матрица монодромии, математическая модель, асинхронный двигатель, уравнение состояния.

Kostiuchko S.M., Kyryliuk L.M., Kalys O.V., Sibanda Z.F., Havryliuk S.A. The monodromy matrix construction for executive object of a nonlinear system. The article reveals one of a monodromy matrix constructing methods, reveals the essence of the simplest construction and calculation such matrix. This method is used to build a actuator mathematical model, which can be used to study transients and steady-state processes.

Keywords: monodromy matrix, mathematical model, asynchronous motor, state equation.

\section{Problem formulation}

The monodromy matrix of any physical device is used in the steady-state processes, static stability and parametric sensitivity analysis. We will show how to find it in the case of electrical devices using mathematical models on the example of an induction motor with a rotor rectangular groove.

\section{Recent research analysis}

To solve this problem, it was necessary to solve several important theoretical problems, in particular, to develop: a general theory of the electric skin effect, the principle of constructing circuit-field electrical devices mathematical models, and the theory of parametric sensitivity auxiliary model. This became the basis for constructing matrices of monodromy systems.

Mathematical model

The machines rotor winding by the number of turns is considered to be reduced to 125 stator windings. Thus, it is flowed not by physical but by reduced currents. At the same time, these currents appear in the boundary conditions of the electromagnetic field. Therefore, the equation of the electromagnetic circuit also must be reduced together with the currents. For which it is enough to give the environment parameters. The rotor is made in the squirrel wheel form. This is a multi-loop system, which is usually equivalent to two circuits. However, such equivalence should not affect the geometry of the groove space. All groove dimensions must be intact. In the transformed coordinates, the rotor winding currents and voltages also are reduced in frequency to the currents and voltages of the stator winding. The electromagnetic field equation also must be given. The motor's electromagnetic state equation is written in the form

$$
\frac{d \mathbf{i}}{d t}=\mathbf{A}\left(\mathbf{u}-\mathbf{\Omega}^{\prime} \Psi-\mathbf{R i}\right)
$$

where 


$$
\begin{array}{|l|}
\hline \lambda_{S} \\
\hline \lambda_{R}
\end{array}, \boldsymbol{\lambda}=\mathbf{u}, \boldsymbol{\Psi}, \mathbf{i} ; \mathbf{A}=\begin{array}{|l|l|}
\hline A_{S} & A_{S R} \\
\hline A_{R S} & A_{R} \\
\hline
\end{array} ; \mathbf{\Omega}^{\prime}=\begin{array}{|l|l|}
\hline & \\
\hline & \mathbf{\Omega} \\
\hline
\end{array} ; \mathbf{R}=\begin{array}{|l|l|}
\hline \mathbf{R}_{S} & \\
\hline & \mathbf{R}_{R} \\
\hline
\end{array}
$$

Here $\mathbf{i}_{k}=\left(i_{k A}, i_{k B}\right)_{t}, k=S, R$ are columns of stator winding phase currents and the rotor winding converted currents; $\mathbf{u}_{k}=\left(u_{k A}, u_{k B}\right)_{t}, k=S, R$ are the stator winding phase voltages columns; $A_{S}, A_{S R}, A_{R S}, A_{R}$ are matrixes

$$
A_{S}=\alpha_{S}\left(1-\alpha_{S} \mathbf{G}\right) ; A_{S R}=A_{R S}=-\alpha_{S} \alpha_{R} \mathbf{G} ; A_{R}=\alpha_{R}\left(1-\alpha_{R} \mathbf{G}\right),
$$

where $\mathrm{G}, \Omega$ are matrixes

$$
\mathbf{G}=\begin{array}{|c|c|}
\hline T+b_{A} i_{A} & b_{B} \\
\hline b_{A} i_{B} & T+b_{B} i_{B} \\
\hline
\end{array}, \mathbf{\Omega}=\frac{\omega}{\sqrt{3}} \begin{array}{|c|c|}
\hline-1 & -2 \\
\hline 2 & 1 \\
\hline
\end{array}
$$

moreover

$$
\begin{gathered}
b_{A}=b\left(2 i_{A}+i_{B}\right) ; b_{B}=b\left(i_{A}+2 i_{B}\right) ; b=\frac{2}{3} \frac{R-T}{i_{m}^{2}} ; \\
R=\frac{1}{\alpha_{S}+\alpha_{S}+\rho} ; T=\frac{1}{\alpha_{S}+\alpha_{S}+\tau} .
\end{gathered}
$$

Here $\tau, \rho$ are inverse static and differential inductances, they are found by the characteristic of magnetization (idling) of the machine as:

$$
\tau=\left[\frac{\psi_{m}\left(i_{m}\right)}{i_{m}}\right]^{-1} ; \rho=\left[\frac{d \psi_{m}\left(i_{m}\right)}{d i_{m}}\right]^{-1},
$$

where $i_{m}$ is the module of spatial vector of magnetization currents

$$
i_{m}=2 \sqrt{\left(i_{A}^{2}+i_{A} i_{B}+i_{B}^{2}\right) / 3} ; i_{A}=i_{S A}+i_{R A} ; i_{B}=i_{S B}+i_{R B} .
$$

In the absence of saturation, the magnetization characteristic degenerates directly $i_{m}=\alpha_{m} \psi_{m}$, where $\alpha_{m}$ is the main inverted inductance, and the matrix (4) according to (6) degenerates into a diagonal

$$
\mathbf{G}=\begin{array}{c|l|l|}
1 & 1 & \\
\hline \alpha_{S}+\alpha_{R}+\alpha_{m} & & 1 \\
\hline
\end{array}
$$

which greatly simplifies the equation (1). In this case, we obtain the simplest of all known the induction motor mathematical models. $\mathbf{R}_{S}, \mathbf{R}_{R}$ are resistance matrix

$$
\mathbf{R}_{S}=\begin{array}{|l|l|}
\hline r_{S} & \\
\hline & r_{S} \\
\hline
\end{array} ; \mathbf{R}_{R}=\begin{array}{|l|l|}
\hline r_{R} & \\
\hline & r_{R} \\
\hline
\end{array}
$$

moreover $\alpha_{S}, \alpha_{R}$ are inverse inductances of dissipation of stator and rotor windings; $r_{S}$ is stator phase resistance; $r_{R}$ is the resistance of the rotor winding; $\Omega$ are angular velocity matrix $\omega$.

The column's components of complete flux couplings of the stator and rotor windings are found as follows

$$
\Psi_{k j}=\frac{1}{\tau}\left(i_{S j}+i_{R j}\right)+\frac{1}{\alpha_{k}} i_{k j}, j=A, B ; k=S, R .
$$

Column's elements of a stator and rotor voltages

$$
u_{S}=\left(U_{m} \sin \left(\omega_{0} t\right), U_{m} \sin \left(\omega_{0} t-120^{\circ}\right)\right)_{t} ; u_{R}=0,
$$

where $U_{m}, \omega_{0}$ are amplitude and circular frequency of network voltage.

The equation of mechanical state has the form

$$
\frac{d \omega}{d t}=J\left(M_{E}-M\right) / p_{0}
$$

(C) Kostiuchko S.M., Kyryliuk L.M., Kalys O.V., Sibanda Z.F., Havryliuk S.A. 
moreover

$$
M_{E}=\sqrt{3} p_{0}\left(\Psi_{S A} i_{S B}-\Psi_{S B} i_{S A}\right),
$$

where $M(\omega)$ is mechanical moment; $p_{0}$ is the magnetic poles number of pairs; $J$ is the moment of rotor inertia; $M_{E}$ is electromagnetic moment.

System of differential equations (1), (12) are mathematical A-model of the actuator (asynchronous motor). It is intended for the transient and steady-state processes analysis. For its practical use it is necessary to know the following object parameters: stator and rotor windings dissipation supports and inverse inductances; idle characteristic, and without taking into account the saturation of the main magnetic circuit - the machine's inverse main inductance, the magnetic poles number of pairs and the rotor inertia moment. The input signals are: phase supply voltages and mechanical torque on the shaft.

\section{Monodromy matrix construction}

When constructing an auxiliary sensitivity model, we form a unknowns column $\mathbf{y}$

$$
\mathbf{y}(t)=(\Psi, \omega)_{t} .
$$

The monodromy matrix is written in the form (everywhere later the matrix $\mathbf{S}=\mathbf{z}$ )

$$
\mathbf{\Phi}=(\mathbf{A z}, \mathbf{w})_{t},
$$

Thus, the executive object's monodromy matrix construction to requires the integration the first variation's equations $\frac{d \mathbf{z}}{d t}$ and $\frac{d \mathbf{w}}{d t}$ :

where

$$
\frac{d \mathbf{z}}{d t}=-(\mathbf{\Omega}+\mathbf{R A}) \mathbf{z}-\frac{\partial \mathbf{\Omega}}{\partial \omega} w \mathbf{\Psi}
$$

$$
\mathbf{z}=\frac{\partial \Psi}{\partial \mathbf{x}(0)} ; \mathbf{w}=\frac{\partial \omega}{\partial \mathbf{x}(0)}
$$

Matrix $\partial \mathbf{\Omega} / \partial \omega=$ const . The matrix structural form can be determined using the equation $\boldsymbol{\Omega}=\operatorname{diag}\left(1, \mathbf{\Omega}_{R}\right)$ and formula

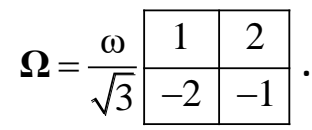

$$
\begin{aligned}
& \frac{d \mathbf{w}}{d t}=\frac{p_{0}}{J}\left(\sqrt{3} p_{0}\left(\frac{\partial \Psi_{S}}{\partial \mathbf{x}(0)} \times \mathbf{i}_{S}+\Psi_{S} \times \frac{\partial \mathbf{i}_{S}}{\partial \mathbf{x}(0)}\right)-\frac{\partial M(\omega)}{\partial \omega} w\right) .
\end{aligned}
$$

On the s-th iteration of Newton's formula

$$
\mathbf{x}(0)^{(s+1)}=\mathbf{x}(0)^{(s)}-f^{\prime}\left(\mathbf{x}(0)^{(s)}\right)^{-1} f\left(\mathbf{x}(0)^{(s)}\right),
$$

linear variational equations (16), (19) are subject to compatible integration with nonlinear (1), (12) on the time interval $[0, \mathrm{~T}]$.

The proposed analysis method has received a comprehensive test in complex problems of electromechanics. And it turned out to be very effective.

\section{Conclusions}

Determination of the electrical devices monodromy matrix is most simply carried out on the basis of integrating the first variation equations of the differential equations of device's state. Only on the basis of the monodromy matrix there is a practical possibility to build general algorithms for the analysis of physical devices in full, using the general theory similar mathematical apparatus of nonlinear differential equations. This applies to the analysis of transients and steady-state processes, determining the static stability of the found steady-state processes and, finally, to find parametric sensitivities matrices in transient and steady-state processes. 


\section{References}

1. G. Nalecz. Application of Sensitivity Methods to Analysis and Synthesis of Vehicle Dynamic Systems. // Vehicle System Dynamics, 18 (1989), 0042-3114/89/1801-0001, Swets \& Zeitlinger, pp. 1-44.

2. Tchaban V. Auxiliary model of parametric sensitivity / Vasil Tchaban, Serhiy Kostiuchko, Zorana Tchaban // Computational Problems of Electrical Engineering. - Lviv, 2012. - V. 2, № 2. - P. 105-111.

3. Lyashko S.I. Generalized Optimal Control of Linear Systems with Distributed Parameters / Dordrecht, Boston, London. Kluwer Academic Publishers. - 2002. - 455 p.

4. Aprile T.I. A computer algorithm to determine the steadystate responce of non-linear oscilators / Aprile T.I., Trick T.N. // IEEE, Trans. Circuit Theory. - 1972. - vol. 19. - P. 354-360.

5. Korn G. Mathematical handbook for scientists and engineers / Korn G., Korn T. Toronto, London: Mc. Graw-Hill book comp. 1996. $-720 \mathrm{p}$.

6. Tomovic, R., Sensitivity Analysis of Dynamic Systems, McGraw-Hill Book Co., New York, 1963.

7. Brayton, R. K., Spence, R., Sensitivity and Optimization, Elsevier, New York, 1980.

8. Frank, P. M., Introduction to System Sensifivity Theory, Academic Press, New York, 1978.

9. Kelley, H. J., "Method of Gradients", Optimization Techniques with Applications to Aerospace Systems, edited by George Leitmann, Academic Press, Orlando FL, 1962.

10. Schmit, L. A., Jr., "Structural Synthesis - Its Genesis and Development", AIAA Journal, v. 19, 1981, pp. $1249-1263$.

11. McKeown, J. J., "Parametric Sensitivity Analysis of Nonlinear Programming Problems", Nonlinear Optimization - Theory and Algorithms, edited by L. C. W. Dixon, E. S. Spedicato and G. P. Szego, Birkhauser, Boston, 1980.

12. McKeown, J. J., "An Approach to Sensitivity Analysis", Numerical Optimization of Dynamic Systems, North Holland, edited by L. C. W. Dixon and G. P. Szego, 1980, pp. 349-362.

13. Vanderplaats, G. N., Yoshida, H., "Efficient Calculation of Optimum Design Sensitivity", AIAA Paper 84-0855, 1984.

14. Youngbok Kim. A study on the control system design for ship mooring winch system. - Journal of Mechanical Science and Technology 28 (3) (2014) 1065 1072 www.springerlink.com/content/1738-494x, DOI 10.1007/s12206-013-1181-9.

15. O. M. Amao and T. I. Fossen, Finite element modeling of mooring lines, Mathematics and Computers in Simulation, 53 (2004) 415-422.

16. P. I. Barth Berntsen, O. M. Amao and B. J. Leira, Ensuring mooring line integrity by dynamic positioning: Controller design and experimental tests, Automatica, 45 (2009) 1285-1290.

17. D. Lee, J. Kim and H. Kim, Design of an automatic winch system for small fishing vessel, Bulletin of Korean Society of Fisheries Technology, 36 (3) (2000) 157-166.

18. D. Lee, Dynamic characteristics of a hydraulic fishing winch simulator, Korean Journal of Fisheries and Aquatic Sciences, 37 (4) (2004) 330 - 336.

19. D. Lee and S. Chun, Characteristics of ship winches and their hydrostatic drives, Journal of the Korea Society of Fluid Power \& Construction Equipment, 4 (2) (2007) 27 - 34.

20. Y. An, Driving characteristics improvement of SRM winch system using torque sharing function, Journal Of the Korean Society of Marine Engineering, 31 (4) (2007) 433-440.

21. J. Ha, D. Han and G. Han, The study for improve the braking power of mooring winch brake, Proceedings of 2008 Autumn Conference of KSME, (2008) 512-517.

22. S. Kostiuchko and V. Tchaban, "Variational Method of Auxiliary Equations in Nonlinear Systems Analysis and Synthesis Problems," 2019 IEEE 20th International Conference on Computational Problems of Electrical Engineering (CPEE), LvivSlavske, Ukraine, 2019, pp. 1-5, doi: 10.1109/CPEE47179.2019.8949123.

23. S. Kostiuchko, O. Kuzmych, A. Aitouche, S. Grinyuk and O. Mekush, "Application of Parametric Sensitivity Method to Analysis of Automatic Mooring Winch with Electric Drive System," 2019 4th Conference on Control and Fault Tolerant Systems (SysTol), Casablanca, Morocco, 2019, pp. 294-299, doi: 10.1109/SYSTOL.2019.8864751. 